\title{
The Environmental Impact of COVID-19
}

Mohd Kafeel Ahmad Ansari ${ }^{1}$, Nasreen Islam Khan ${ }^{2}$ and Gary Owens ${ }^{3}$

1. Cyanobacterial Biotechnology Laboratory, Department of Biosciences, Jamia Millia Islamia (Central University), New Delhi-110025, India

2. School of Environment and Society, Australian National University, Canbera, ACT 0200, Australia.

3. Future Industries Institute, University of South Australia, Mawson Lakes, SA 5095, Australia

https://www.scopus.com/authid/detail.uri?authorld=35319667300

\section{E-mail: kafeelansari123@gmail.com}

\begin{abstract}
COVID-19, previously known as "2019 novel coronavirus", is a newly discovered virus which causes severe acute respiratory syndrome, similar to corona virus 2 (SARS-CoV-2), which has spread widely through human to human contact and was declared a pandemic by the WHO in March 2020. To cope with this pandemic many countries have adopted nationwide lockdowns which restrict nonessential activities and encourage their populations to avoid public transport, work from hone wherever possible, and to maintain social distancing at all times. While the severity of these shutdowns has varied with country, large geographic regions of the world (including China, India, Iran, Italy, Spain, and the USA) have all been severely affected, not just in the loss of human life, but also in terms of the financial impacts the lockdowns will have on their countries future prosperity It was previously reported that a number of environmental factors, including humidity and temperature, played an important role in development and spread of the SARS-Corona Virus infection with the virus retaining viability for over 5 days at temperatures between $22-25^{\circ} \mathrm{C}$ and relative humidity $(\mathrm{RH})$ of $40-50 \%$. Whereas, elevated temperatures and higher $\mathrm{RH}$
\end{abstract}


$\left(38^{\circ} \mathrm{C}\right.$, and $\left.>95 \% \mathrm{RH}\right)$ decreased virus viability (Kroumpouzos et al., 2020). The spread of COVID-19 started in low temperature areas of China, with major outbreaks subsequently occurring in Iran, Japan, Northern Italy and South Korea. These new virus epicenters all had similar temperature and latitude, along the $30-50^{\circ}$ N" zone. Subsequently, the virus was spread to regions of elevated temperature, such as India, the Middle East and Thailand, due to international travel (Kroumpouzos et al., 2020).

The aim of this study was to consider the environmental impact of COVID-19, including water pollution. The paper is divided into four sections. In the first section the current literature related to COVID-19 is reviewed. In the second section a recent update on COVID19 globally is presented, followed by a descriptive impact on the environment in the third section and finally in the fourth section the COVID-19 related worldwide environmental impact is discussed. Since COVID-19 is a currently an active pandemic with no end in sight, while constructive conclusions can only be made on the limited data currently, which may be prone to high errors. However, these conclusions may provide some preliminary suggestions for assisting in assessing spreading patterns of COVID-19 across the globe, and may be of long-term significances with respect to assessing the environmental impact of lockdown policies due to COVID-19 worldwide.

Keywords: COVID-19; Corona virus; climate change; environmental impact; SARS-CoV-2

\section{Introduction}

The COVID-19 outbreak, which first appeared in Wuhan, China in December 2019, rapidly spread to the rest of the world, including Asia, Europe and the United States, within just a few months (Renda and Castro, 2020), resulting in the World Health Organization (WHO) to 
declared a global health emergency in January 2020 (Arora et al 2020; Conforti et al 2020; Sohrabi et al 2020).

Globally, by 14 September 2020 with confirmed cases surpassing 29,185,779 and reported deaths approaching 9, 28, 290 several governments worldwide responded by imposing harsh containment and quarantine rules (Renda and Castro, 2020; WHO 2020). The distribution of COVID-19 cases worldwide, as of 15 July 2020 (European Centre for Disease Prevention and Control) can be seen in (Fig 1 a,b). Previously known by the provisional name 2019novel coronavirus (2019-nCoV), corona virus 2 (SARS-CoV-2), a strain of corona virus was subsequently recognized as COVID-19 (Chen and Li 2020; El-Feky et al. 2020). SARS-CoV2 is a zoonotic coronavirus known to cross species to infect human populations, with subsequent efficient human-to-human virus transmission.SARS-CoV-2 has already spread to over 200 countries worldwide (Anjum et al., 2020).

Therefore, the world is trying to find efficient approaches to control rapid transmission of COVID-19 to avoid its spread to the human-to-human. Previous studies have suggested that a number of environmental factors, including humidity and temperature, may play important roles in development and spread of SARS-Corona Virus infection, since the virus retained viability for over 5 days at temperatures of between $22-25^{\circ} \mathrm{C}$ and relative humidity (RH) of 40-50\%, whereas elevated temperatures and higher $\mathrm{RH}\left(38^{\circ} \mathrm{C}\right.$, and $\left.>95 \% \mathrm{RH}\right)$ decreased virus viability (Kroumpouzos et al., 2020). Since COVID-19 initially started in low temperature areas of China, with subsequent major outbreaks in Iran, Japan, Northern Italy and South Korea, where these new virus epicentres had similar temperature and latitude, i.e. were all along the $30-50^{\circ} \mathrm{N}$ " zone. The outbreak of disease was subsequently extend to more elevated temperature regions like India, the Middle East and Thailand, due to international travel (Kroumpouzos et al., 2020). 
Therefore, to avert COVID-19 spread, various countries are adopting the stratagem of practicing social distancing and advising people to stay safely in their homes throughout an extended period of strict global lockdown. Worldwide, the streets of the cities are forsook; the usually hustling bars, pubs and theatres have been closed; operation of public transport has been confined and most governments have released advisories to their citizens to work remotely from their homes. Since $24^{\text {th }}$ March 2020 to the third week of April 2020 (Fig. 2), a four-week nationwide lockdown has crippled large geographic areas impacting economies and the environment across the globe (Anjum et al., 2020). Therefore, in the Fig. 2, there are two different types of colors namely; redish pale yellow (before lock-down) which showed high PM 2.5 level, however, on the other side, green color (after lock-down) clearly indicated normal degree of PM 2.5, respectively. Moreover, it is clearly depicted that particulate matter (PM 2.5) level decreased during four week lock down as it can be seen in green color in comparison of before lockdown period shown in redish pale yellow, respectively. Likewise, the decreased $\mathrm{NO}_{2}$ level has been reported in this period (Fig.2.).

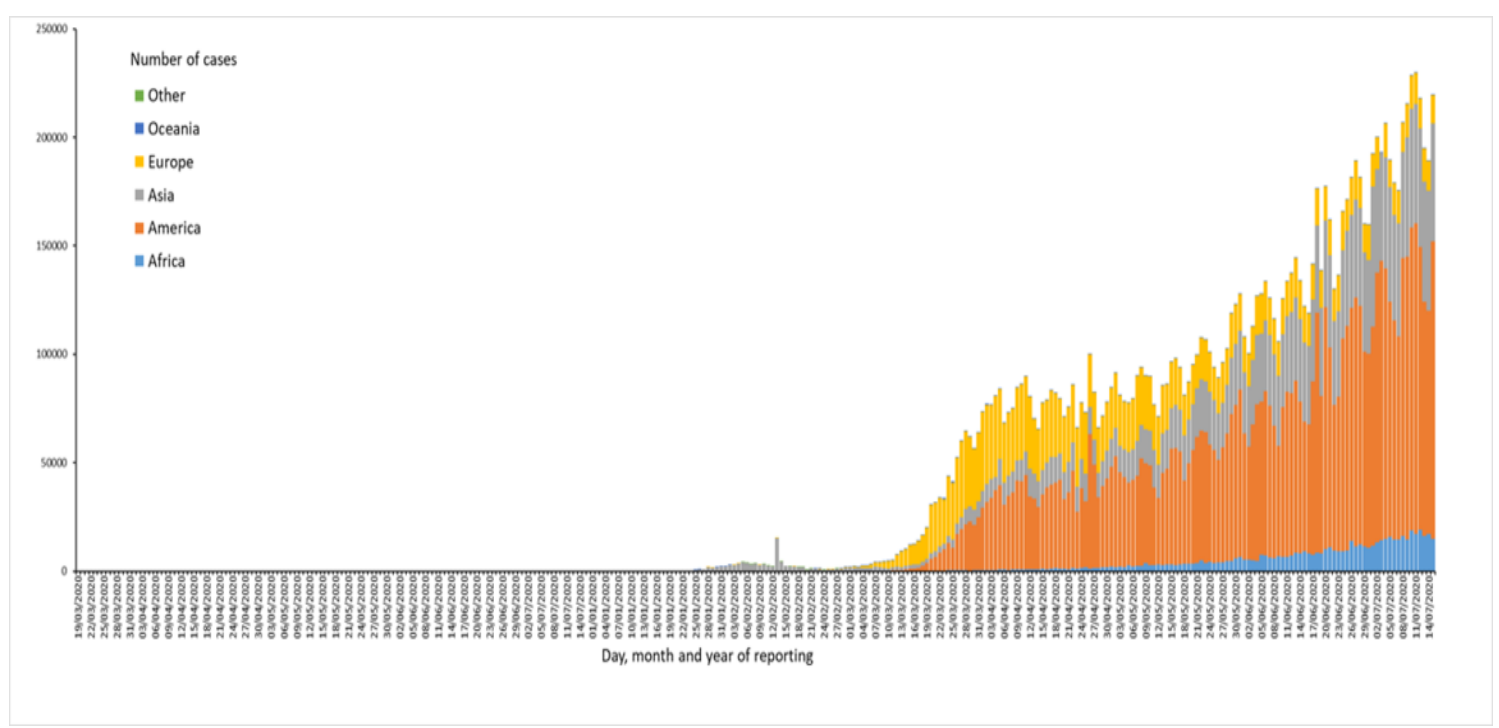

Fig. 1a. Distribution of COVID-19 cases worldwide, as of 15 July 2020 (European Centre for Disease Prevention and Control, https://www.ecdc.europa.eu/en/geographical-distribution2019-ncov-cases). 


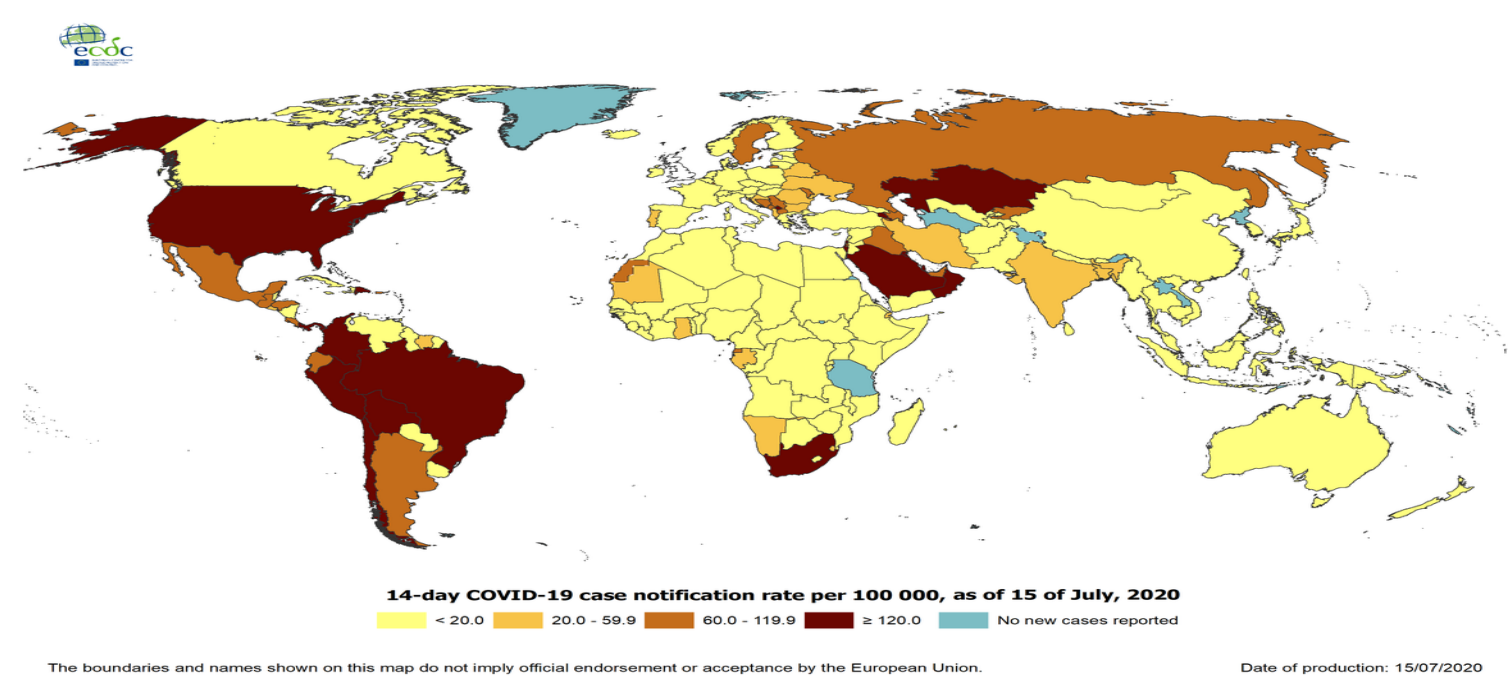

Fig.1b. Geographical distribution of COVID-19 cases as of 15 July 2020 - worldwide (European Centre for Disease Prevention and Control, https://www.ecdc.europa.eu/en/geographical-distribution-2019-ncov-cases).
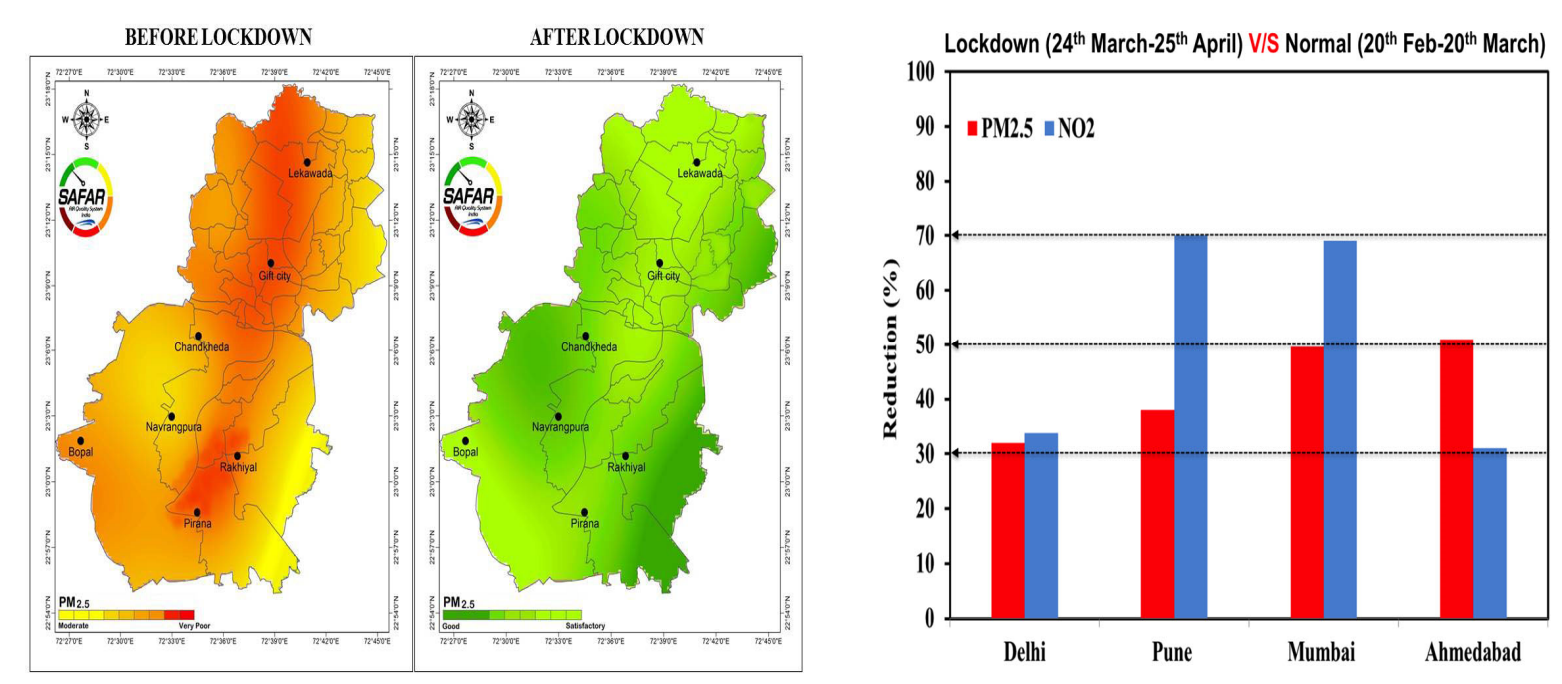

Fig. 2. Ahmedabd: Before Lockdown $\left(24^{\text {th }}\right.$ March- $25^{\text {th }}$ April, 2020) v/s After Lockdown (24 $4^{\text {th }}$ March-25 ${ }^{\text {th }}$ April, 2020) [Updated: 7th May 2020] (SAFAR-India, 2020). (A radish pale yellow color showed the elevated PM 2.5 level before nationwide lock-down whereas green color described normal level of PM 2.5 after lock-down).

\section{Global environmental impact of COVID-19}


While COVID-19 has no direct impact on the environment, a number of literature review and media reports have revealed potential for indirect climate impact resulting from the corona virus-related lockdown (Hasan Eroğlu, 2020). Europe has come to a virtual standstill, like most countries globally who are experiencing some kind of lockdown, which many assume will be good for the environment. For example, nitrogen dioxide air pollution levels have dropped sharply across the Europe (Balken Green Energy News, 2020) since the continent went into lockdown (Fig 3). Likewise, a decreased PM 2.5 level was also reported during this lockdown period in India (Fig.2). This is not surprising given that $\mathrm{NO}_{2}$ emission are well known to be mainly associated with the burning of fossil fuels at elevated temperatures via combustion of fuel in engines and that this would have been significantly curtailed by the decrease in road traffic and industry activity during the lockdown. In a time of health crisis this has some potential for increase health outcomes because as the Director of the Copernic Atmosphere Monitoring Servicer, Vincent-Henri Peuch, explained high levels of air pollution normally detrimentally affects cardio-pulmonary health, so that less air pollution in a time or COVID19 was good news which is indirect result of the environmental impact (Balken Green Energy News, 2020).

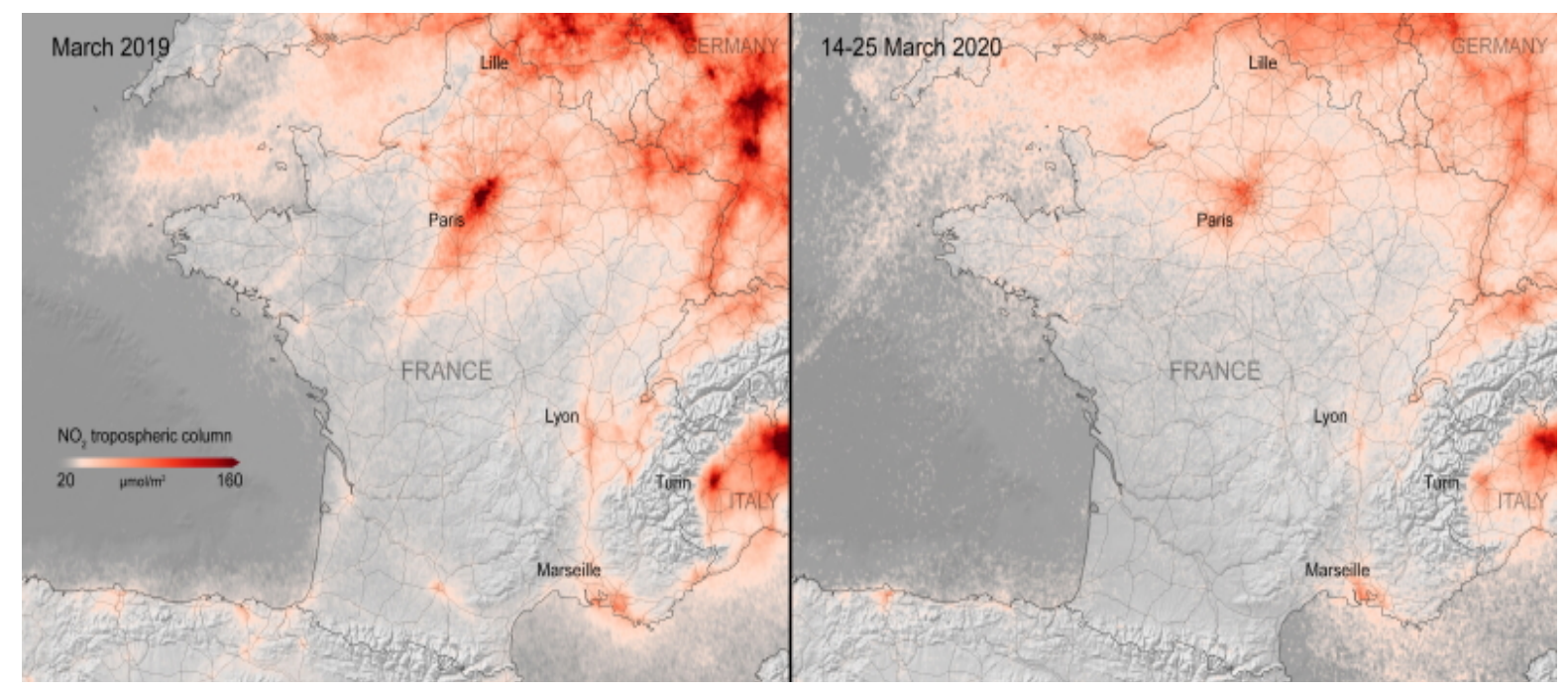

Fig. 3. Images taken one year apart, pre- (March 2019) and post- (March 2020) COVID19 demonstrating a decline in $\mathrm{NO}_{2}$ emissions (red shading) in major cities of France due to 
COVID-19 lockdowns, where darking shading indicate increasing levels of $\mathrm{NO}_{2}$ (image credit: Balkan Green Energy News 2020).

Since COVID19 may be transported and remain viable on contaminant particles (Euronews, 2020, less air pollution should also reduce potential virus spread. While this issue is scientifically contentious, the President of the Italian Society of Environmental Medicine, Dr. Alessandro Miani, mentioned that particulate matter (PM) is supposed to be atmospheric pollution that can be considered a highway for epidemic acceleration (Euronews, 2020). In India air pollution had also significantly dropped by the end of the second week of the COVID-19 lockdown. The air quality index (AQI; range 0-500) gives an overall appraisal of general air quality which is categorised as either good (0-50), satisfactory (51-100) or; poor (201-300). However, as of March 29, 2020 (SAFAR-India 2020; Vishnoi 2020) a total of 91 cities classified as having 'Good' or 'Satisfactory' AQI, with 31 cities being classified as 'Good'; with no city considered to be in the 'Poor' AQI category (Fig. 4). Additionally, the shutdown measures associated with COVID-19 have also led to a plummet in PM 2.5, decreasing by 15, 30 and 15\% in Ahmedabad, Delhi and Pune, respectively (The Hindu 2020).

In New Delhi, the diversion and/or cessation of flights witnessed a $71 \%$ plummet in air pollution within one week, where the level of PM 2.5 decreased from 91 micrograms per cubic meter (on 20 March 2020) to only 26 micrograms per cubic meter within a couple of days of the lockdown being imposed (Davidson 2020). Similarly, the earlier, the 'Janata Curfew', observed on March 22 (from 7 am-9 pm) also led to a noteworthy decrease in both particulate matter $\left(\mathrm{PM}_{10}\right)$ and nitrogen oxide $(\mathrm{NOx})$ levels, where a $44 \%$ decline in $\mathrm{PM}_{10}$ was observed mainly in Delhi between $22^{\text {nd }}$ and $23^{\text {rd }}$ of March 2020 (FP 2020). 
Air Quality Across SAFAR Cities: AQ-Index

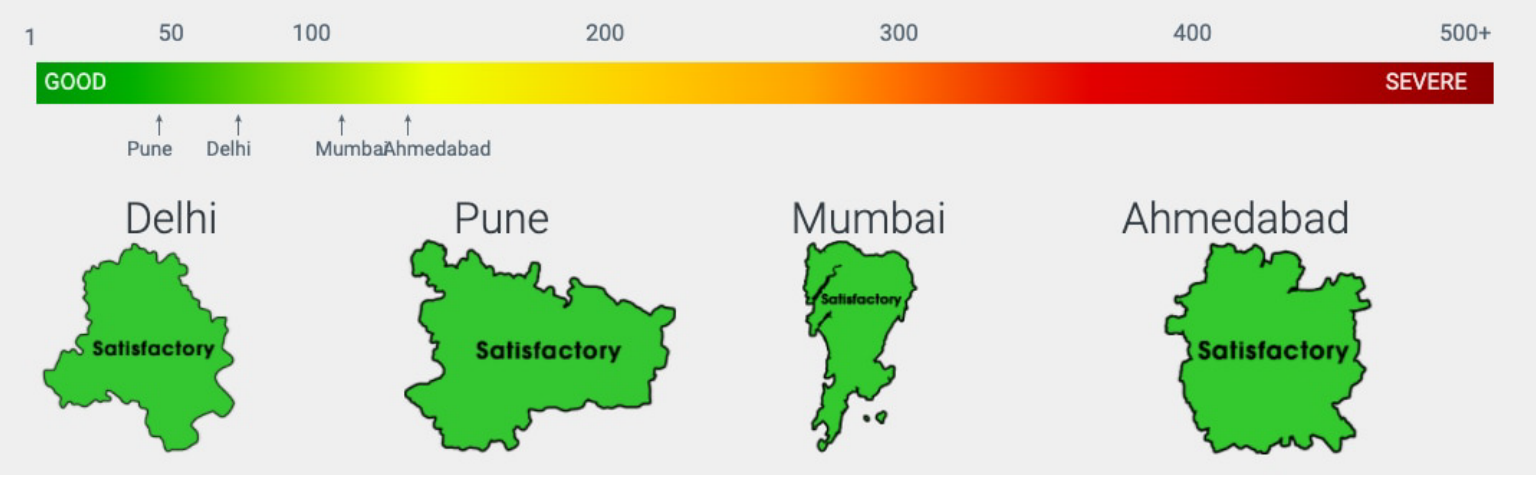

Fig. 4. Image showing air quality across major cities in India as on 27th March 2020 (SAFAR-India 2020).

\subsection{Climate change due to corona virus}

While the COVID19 pandemic has had an obvious and dramatic impact on our work environments, the effect on the natural environment is far less obvious (Hasan Eroğlu, 2020; IPCC, 2020).Vincent-Henri Peuch supposed that the present situation may have a huge influence on our approach to tackling pollution. Certainly, the experiences learnt from pandemic lockdown provide important insights in to tackling the problem of air contamination (Hasan Eroğlu, 2020).

While air pollution and green house gas emissions have decreased across continents as individual countries close their industries activities in an attempt to hold the spread of COVID19, it is unclear if this abrupt momentous change short-term or could it actually lead to durable decreases in emissions? The imposed inactivity over large large geographic areas has also led to some unforeseen temperate changes due to decreased air pollution in most parts of the globe, including China, California and Italy (Calma 2020 a,b). In addition to pollution, greenhouse gas emissions have also decreased across most landmasses (Henriques 2020). This is not surprising given that the transport sector's greenhouse gas emissions from 
driving and aviation contributed about 72 and $11 \%$, to total greenhouse gas emissions (IPCC 2020).

Within a few months, the world has been transformed, tens of thousands of people have died, hundreds of thousands have directly suffered from a previously unheard of novel corona virus and billions of people not directly affected by the disease have been forced to change their usual way of life completely (Hasan Eroğlu, 2020).

Following an unprecedented severe lockdown by authorities on the streets of Wuhan, China, are isolated (Hasan Eroğlu, 2020). Likewise, in Italy, the most panoptic travel restrictions since World War II have been imposed. Similarly, in London, the usually busy bars, pubs, and theatres have been closed and people have been advised to stay in their homes for their safely. Globally flights have being cancelled, as the aviation industry buckles to due corona virus induced travel restrictions and border closures. A large number of countries have adopted social distancing and remote working strategies, which have been designed to quickly control the spread of COVID19, and hopefully reduced the rapid increase in the global death rate. All of these sudden changes have also led to a few unforeseen consequences. The closure of businesses, industries and transport networks has resulted in a rapid drop in carbon emissions. For example, the levels of air pollution in New York were reduced by nearly $50 \%$ because of measures to contain the corona virus compared to levels record in the previous year (Hasan Eroğlu, 2020).

According to China's Ministry of Ecology and Environment, since the last quarter of 2019, in China alone, emissions had decreased by up to $25 \%$ at the beginning of this year as people were advised to stay at home, factories were closed and coal use by China's six largest power plants decreased by 40\% (Myllyvirta 2020). Amongst 337 Chines cities the proportion of good quality air also increased by $11.4 \%$ compared to the same time last year. While in 
Europe, satellite images demonstrated that nitrogen dioxide $\left(\mathrm{NO}_{2}\right)$ emissions decreased over northern Italy, with similar observations in Spain and the UK (Hasan Eroğlu, 2020).

An experiential threat like COVID19 could have led to such a profound change so fast; as yet worldwide deaths from this virus reached up to more than $9,28,990$ with more than 29,185 , 779 cases have been confirmed globally. The pandemic has also resulted in a large number of job losses, which has consequentially threatened the livelihoods of millions of people due to the restrictions on businesses being imposed to control the virus spread worldwide. Economic activity has almost ceased and stock markets have tumbled. This result is at odds with the slow drive towards a decarbonised, sustainable economy advocated by many economist for last decade (BBC English, 2020).

While the current international corona virus pandemic has claimed tens of thousands of people's and shattered economies it may have also delivered positive environmental change as an unexpected side effect. While atmospheric emission from industrial activity have plunged, it is uncertain how long such drops in emissions will persist, especially as countries roll back their self imposed restrictions in attempt to restart their economies. When the pandemic ultimately subsides, will carbon and contaminant emissions "bounce back" too much so that it will be as if this clear-skied interlude never happened? Or could the changes we see today have a more persistent effect (BBC English, 2020).

\subsection{Effect of COVID19 lockdown on Ganga water pollution}

Aditi Sharma, Officer for the Department of Forest, Government of Delhi (http://forest.delhigovt.nic.in/wps/wcm/connect/DOIT_Forest/forest/home) acknowledges that pollution has been plummeting since local industries have completely closed and people's movement has also been restricted. The water quality of the tributaries of Ganga, such as Hindon and Yamuna, has also improved significantly. Aditi Sharma also indicated 
that the quality of the Ganges water was likely to improve further as the lockdown continued. While no one has been currently able to find pollution problems with the Ganga between Aligarh and Narora, no official report has yet been released by the government regarding the improvement in the water quality of the rivers (Hindustan, 2020).

The climate of the country has also been changing due to the lockdown. During this time, the level of pollution has been constantly declining. According to environmentalists, since 22 March there has been a dramatic decrease in the pollution of Ganges and many other rivers passing through West Uttar Pradesh including Meerut. Environmentalists including Dr. Girish Shukla, Dr. Yashwant Rai and Priyank Bharti (Natural Sciences Trust President) reported that various industries polluting the Ganga were closed due to complete lockdown. In many cities of West UP, for example, Aligarh, Baghpat, Bijnor, Meerut and Muzaffarnagar, industrial waste is commonly dumped in the other small rivers. At present, the Ganges has been purified due to shut down of industrial units. The Central Pollution Control Board, New Delhi has also now described the quality of the Ganges river as fit for wildlife and fisheries along with bathing for people (Times now, 2020).

\subsection{Impact of COVID19 lockdown on Yamuna river water pollution}

A significant decline in the water pollution of the Yamuna river was observed due to the shut down of industrial units during the 21-day lockdown imposed and response to the COVID-19 pandemic. According to Raghav Chadha, Vice-Chairman of Delhi Jal Board, the shutting of industrial units in Delhi-NCR during the lockdown led to an apparent increase in the water quality of the Yamuna river as tons of effluent and toxic wastes could not be discharged into the river, Today the Yamuna looks cleaner than it ever has before, indicating that cessation of efflux of industrial contaminants and industrial waste has definitely had a constructive consequence quality. 
The significant visual improvement in water quality following this brief period is a promising indiactor that there is a strong chance for the Yamuna to be cleaned up easily if people and the government work together. The common people, those who usually come to the river banks for morning walks and physical exercise, and those who have been monitoring the Yamuna for many years have also claimed that there has been an overall increase in water quality.

However, the Yamuna is not the only river in the country which has witnessed dramatic increases in water quality due to the national lockdown. The quality of water in the holy Ganga river has also significant improved by up to $40-50 \%$ since March 24 2020, the day when the national 21-day lockdown was announced (Fig. 5).

Since it is well known that one-tenth of the pollution of the Ganga comes from unplanned industries; therefore, as industries shutdown, it is not surprising that the state of the river has become better. Dr PK Mishra, Professor at Chemical Engineering and Technology, IIT-BHU stated that a $40-50 \%$ increases in the cleanliness of the Ganges during national lockdown, was a significant development. He also added that due to rainfall on March 15-16 in the catchment areas of the Ganga flow, the water level had also been augmented, which meant that the innate cleaning capacity of the river had also been amplified. Compared with the pre-lockdown period there had been a considerable improvement after March 24 (Times now, 2020). 


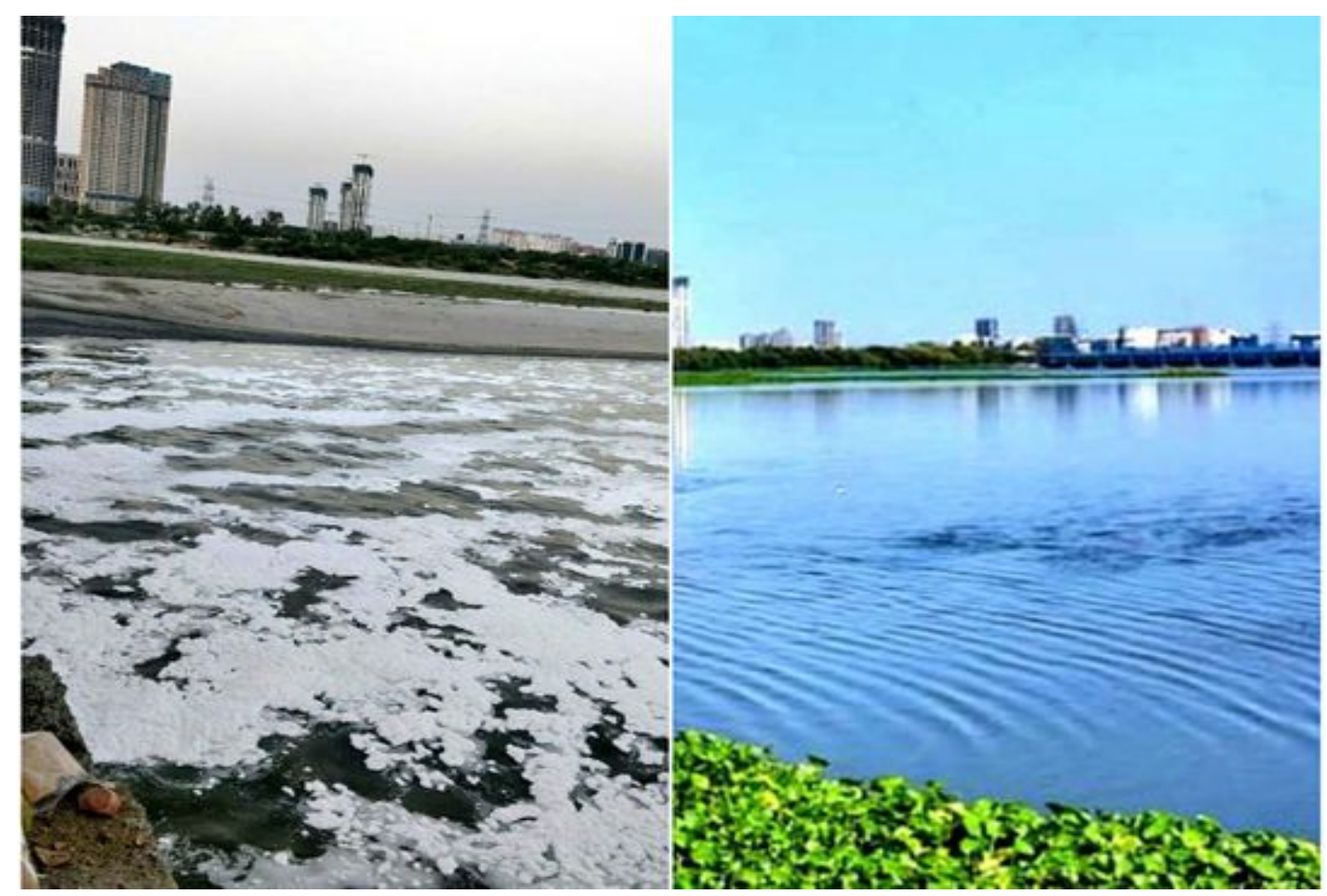

Fig. 5. Corona virus: Impact on Yamuna water (Image Credit, Twitter@SudhaRamen IFS, Asia World, 05 April, 2020)

\subsection{Ganga water made potable}

According to a report published in the Times of India, the corona epidemic has had a constructive impact on the Ganga river, which is now cleaner than ever before. Factories polluting the Ganges are completely closed owing to the lockdown and simultaneously the ghats (valleys) along the Ganges are also bunged. During lockdown, the quality of the Ganges water has improved in Rishikesh and Haridwar, Uttrakhand so that after decades there is some hope that the water of the Ganges of the Har-Ki-Pauri could once again be potable. 14 Apr, 2020, (The Times of India).

The Environment Conservation Association (ECA) conducted a study on the impact of the 21 days lockdown on rivers pollution that indicated positive results from three rivers including 
the Indrayani, Mula and Pavana of Pimpri Chinchwad, part of the Metropolitan Region of Pune, Mahrashtra state of India. April, 14, 2020 (Times of India, 2020).

\section{Conclusions and prospects}

Worldwide, over the last decade, there have been many published reports which have showed that water pollution is increasing daily, which has been closely correlated with severe chronic diseases in human. However, the nationwide halting of public transport and closure of major industrial units has resulted in an obvious significant reduction in water pollution of many national rivers including Ganga, Pimpri Chinchwad and Yamuna. While industries play a vital role in economic growth, lift the nationwide lockdown may also turn back the COVID19 pandemic-led decreases in global water pollution, increasing the incidents of severe health issues in the future as well. Hence, the indications that a short-term lock down of industries may have some shorter environmental effects, decreased water and air pollution which obviously maintain environmental quality globally. Moreover, in this study, the affiliation between Covid-19 outbreak and its impact on environment in a global sense was hashed out and also a comprehensive literature review was comported that could be useful for development of further researches on the issue.

\section{References}

Arora P, Jafferany M, Lotti T, Sadoughifar R, Goldust M (2020). Learning from history: Coronavirus outbreaks in the past. Dermatol Ther. 2020 Mar 28:e13343. doi: $10.1111 /$ dth. 13343.

Anjum NA (2020) Good in the Worst: COVID-19 Restrictions and Ease in Global Air Pollution. Preprint doi:10.20944/preprints202004.0069.v1

Balkan Green Energy News (2020) Air pollution sharply falls worldwide on COVID-19 lockdowns, https://balkangreenenergynews.com/air-pollution-sharply-fallsworldwide-on-covid-19-lockdowns/, accessed on 30 March 2020

BBC English (2020) Will Covid-19 have a lasting impact on the environment? March 27, 2020, https://www.bbc.com/future/article/20200326-covid-19-the-impact-of-coronaviruson-the-environment, accessed on 29 March 2020. 
Calma J (2020a) Maps show drastic drop in China's air pollution after coronavirus quarantine. The Verge https:/www.theverge.com/2020/3/2/21161324/coronavirusquarantine-china-maps-air-pollution, accessed on 28 March 2020.

Calma J (2020b) Air pollution could make the COVID-19 pandemic worse for some people. The Verge https://www.theverge.com/2020/3/19/21186653/coronavirus-covid-19-airpollution-vulnerablelung-disease-pandemic, accessed on 28 March 2020.

Conforti C, Giuffrida R, Dianzani C, Di Meo N, Zalaudek I. (2020) COVID-19 and psoriasis: is it time to limit treatment with immunosuppressants? A call for action. Dermatol Ther. 2020 Mar 11:e13298. doi: 10.1111/dth.13298.

Chen Y, Li L (2020) SARS-CoV-2: virus dynamics and host response. The Lancet Infectious Diseases doi:10.1016/S1473-3099(20)30235-8

Davidson J (2020) Eco Watch, India's Air Pollution Plummets in COVID-19 Lockdown. Apr. $\quad 02, \quad 2020, \quad$ https://www.ecowatch.com/india-air-pollution-coronavirus2645617908.html, accessed on 5 April 2020.

European Centre for Disease Prevention and Control (2020) Geographical distribution of COVID-19 cases. Apr 12, 2020, https://www.ecdc.europa.eu/en/geographicaldistribution-2019-ncov-cases, accessed on 15 Apr, 2020.

Euronews (2020) Covid-19 and climate: how much impact is the current lockdown really having on our environment?, April 13, 2020, https://www.euronews.com/2020/04/13/covid-19-and-climate-how-much-impactis-the-current-lockdown-really-having-on-our-environm, accessed on 13 April 2020.

El-Feky M, Bell DJ et al. (2020) COVID-19. Radiopaedia. https://radiopaedia.org/articles/covid-19- 3?lang=us, accessed on 28 March 2020

Eroğlu,H (2020). Effects of Covid-19 outbreak on environment and renewable energy sector. Environment, Development and Sustainability https://doi.org/10.1007/s10668-02000837-4.

FP (2020) First Post. India sees improved air quality during coronavirus lockdown, says CPCB; AQI improves to 'good' in 23 cities, 'satisfactory' in 65. Apr 02, 2020,https://www.firstpost.com/health/india-sees-improved-air-quality-duringcoronavirus-lockdownsays-cpcb-aqi-improves-to-good-in-23-cities-satisfactory-in-658221311.html, accessed on 5 April 2020.

Forest Department (2020) Water pollution has been plummeting as the industries completely closed, April, $\quad 04, \quad 2020$ http://forest.delhigovt.nic.in/wps/wcm/connect/DOIT Forest/forest/home, accessed on 5 April 2020

Gulfnews (2020) Coronavirus: Has India's Yamuna River gotten cleaner during lockdown?, April 05, 2020, https://gulfnews.com/world/asia/india/coronavirus-has-indiasyamuna-river-gotten-cleaner-during-lockdown-1.1586097472778, accessed on 5 April 2020.

Hindustan (2020) Lockdown reduce air pollution in India, 02 Apr, 2020 https://www.livehindustan.com/national/story-good-impact-of-covid-19-riversstarting-to-clear-due-to-lockdown-reduced-air-pollution-3128711.html, accessed on 04 Apr 2020.

IPCC (2020) Intergovernmental Panel on Climate Change (IPCC 2018), Summary for Policymakers. In: Global warming of $1.5^{\circ} \mathrm{C}$. An IPCC Special Report on the impacts of global warming of $1.5^{\circ} \mathrm{C}$ above pre-industrial levels and related global greenhouse gas emission pathways, in the context of strengthening the global response to the threat of climate change, sustainable development, and efforts to eradicate poverty [V. 
Masson-Delmotte, P. Zhai, H. O. Pörtner, D. Roberts, J. Skea, P. R. Shukla, A. Pirani, W. Moufouma-Okia, C. Péan, R. Pidcock, S. Connors, J. B. R. Matthews, Y. Chen, X. Zhou, M. I. Gomis, E. Lonnoy, T. Maycock, M. Tignor, T. Waterfield (eds.)]. World Meteorological Organization, Geneva, Switzerland, 32 pp. ISBN: 978-92-9169-151-7.

Kroumpouzos G, Gupta M, Jafferany M, Lotti T, Sadoughifar R, Sitkowska Z, Goldust M (2020) COVID-19: A Relationship to Climate and Environmental Conditions?

Myllyvirta, L. (2020). Coronavirus has temporarily reduced China's CO2 emissions by a quarter. Carbon Brief. Retrieved April 20, 2020, from https ://www.carbo nbrie f.org/analy sis-coron aviru s-has-tempo raril y-reduc ed-china s-co2-emiss ions-by-aquart er.

Renda A, Castro R J (2020) Towards stronger EU governance of health threats after the COVID-19 pandemic. European Journal of Risk Regulation as part of the Cambridge Coronavirus Collection. DOI 10.1017/err.2020.34

SAFAR - India (2020) System of Air Quality and Weather Forecasting And Research. http://safar.tropmet.res.in/, accessed on 5 April 2020.

Sohrabi C, Alsafi Z, O'Neill N, et al. World Health Organization declares global emergency: A review of the 2019 novel coronavirus (COVID-19). Int J Surg. 2020 Feb 26;76:7176.

The Hindu (2020) Air quality improves amid lockdown in India, 2 Apr 2020, https://www.thehindu.com/news/national/air-quality-improves-in-indiaamidlockdown/ article31234638.ece, accessed on 5 April 2020.

Timesnow (2020) Lockdown impact on water pollution in India, March 24, 2020, https://www.timesnownews.com/mirror-now/in-focus/article/covid-19-lockdownimpact-water-pollution-levels-drop-in-yamuna/574051, accessed 05 April, 2020.

The Times of India (2020) ECA studding impact of Covid-19 lockdown on rivers pollution in Pimpri, April 08, 2020, http://timesofindia.indiatimes.com/articleshow/75039812.cms?utm_source=contentofi nterest\&utm_medium =text\&utm_campaign $=$ cppst, accessed on 8 April 2020

Vishnoi A (2020) Lockdown clears up India's air, Economics Times, Apr 2, 2020,https://economictimes.indiatimes.com/news/politics-and-nation/lockdownclears-up-indiasair/articleshow/74942627.cms, accessed on 5 April 2020.

Westcott B, Marsh J, Woodyatt A (2020) Global coronavirus pandemic kills more than 30,000, CNN, March 29, 2020, https://edition.cnn.com/world/live-news/coronavirusoutbreak-03-29-20-intlhnk/index.html, accessed on 29 March 2020.

WHO (2020) Coronavirus disease 2019 (COVID-19) Situation Report-75. https://www.who.int/docs/default-source/coronaviruse/situation-reports/20200404sitrep-75-covid-19.pdf?sfvrsn=99251b2b-2, accessed on 5 April 2020. 